\title{
Isotope-fractional carbon curves in different types of Lake Baikal oil
}

\section{Iakovlev D.V.*, Prasolov E.M., Petrov V.V., Khabarova A.A., Brylina A.V.}

«A. P. Karpinsky Russian geological research institute» (VSEGEI), Sredny pr. V.O., 7 4, St. Petersburg, 199106, Russia

ABSTRACT. Specialists of VSEGEI conducted research of the carbon isotopic composition in various components of oils from two known oil seep of Lake Baikal (near Tolsty cape and Gorevoy Utes cape). The results of the isotope-fractional analysis are generally consistent with the conclusions obtained Kontorovich A.E. in 2007 during the geochemical research of the composition of oils.

Keywords: Oil seep, Lake Baikal, carbon isotope composition in oil.

\section{Materials and methods}

The research examined three oil samples selected by VSEGEI specialists in two well-known oil seep of Lake Baikal: «Tolstoye» (N107.36E52.64) near Tolsty cape (Zarechye village district) and «Gorevoye» (N108.39E53.31) near Gorevoy Utes cape. Two samples were taken in melting holes on the surface of the ice in April of 2016 («from the ice»). One sample («the bottom») was obtained as a result of penetration into the bottom sediments (depth $885 \mathrm{~m}$ ) in the «Gorevoye» oil seep area with a benthic pipe from the board of the $\mathrm{R} / \mathrm{V}$ «Vereshchagin» in July 2016 (by Shakhverdov V.A.). This sample is characterized by the coexistence of liquid oil and gas hydrates in near-bottom conditions. A study of properly preserved oil samples was conducted in November of 2016.

The specialists of VNIGRI according to their own developed methodology carried out the separation of oil samples into components. The process involves the precipitation of asphaltenes and the separation of maltene fractions into oils, benzene and alcoholbenzene resins on silica gel using various solvents. The oil fraction was divided into saturated (methanenaphthenic) and aromatic hydrocarbons (mono-, biand polyaromatic) by ascending chromatography on silica gel using petroleum ether. The carbon isotopic composition $\left(\delta^{13} \mathrm{C}\right.$ in $\%$, PDB) for both the oil as a whole and for each of its components ( 9 measurements for each oil sample) was determined by the specialists of Central laboratory of VSEGEI on a DELTAplusXL mass spectrometer with a ConFlo II preparative setup, which includes elemental analyzer (Fig. 1).

Based on the literature data (Galimov, 1973; Kontorovich et al., 1989; 2007; Dakhnova et al., 2011; Pavelieva, 2017), the obtained isotopic-fractional carbon curves in the oils of Lake Baikal are compared with similar curves in other oil-bearing regions $\left(\delta^{13} \mathrm{C}\right.$ for «aromatic hydrocarbons (total)» and «resins (total)» of the oils of Lake Baikal calculated as the arithmetic mean of the constituent components) (Fig. 2).

\section{Conclusions}

1. Similarity of the morphology of the isotopefractional carbon curves for different types of Lake Baikal oils as a whole, as well as a narrow dispersion of $\delta^{13} \mathrm{C}$ values for each component indicate the isotopic uniformity of oils and the unity of the oil source.

2. According to $\delta^{13} \mathrm{C}_{\text {«Tolstoyes(from the ice) }}=-27.2 \% 0 \approx$ $\delta^{13} \mathrm{C}_{\text {«Gorevoyes(from the ice) }}=-27.1 \% 0 \approx \delta^{13} \mathrm{C}_{\text {«Gorevoye»(the bottom) }}$ $=-27.1 \% 0$ - different types of oils of Lake Baikal is uniform in the total carbon isotopic composition and is more similar to the oils of the regions of Azerbaijan and the Perm Pre-Urals region connected to Cretaceous and Paleozoic rocks respectively.

3. There is a common trend of gradual enrichment with the ${ }^{13} \mathrm{C}$ heavy isotope in a series from the most isotopic-light methane-naphthenic hydrocarbons to isotope-heavy polyaromatic hydrocarbons (Galimov, 1973, p. 180).

4. Based on $\delta^{13} \mathrm{C}_{\text {benzene resins }}>\delta^{13} \mathrm{C}_{\text {alcohol-benzene resins }}>$ $\delta^{13} \mathrm{C}_{\text {oil }}$, resins can be classified as primary residual (a by-product of the conversion of the oil source material) or they may be a product of secondary changes in oil hydrocarbons (Galimov, 1973, p. 207).

5. According to the results of geochemical research of the composition of different types of oils of Lake Baikal fully represented by Kontorovich et al. (2007), the degree of biodegradation increases in the series «Gorevoye» (from the ice)-«Gorevoye» (the bottom)-«Tolstoye» (from the ice) (decrease until the peaks of n-alkanes and isoprenoids almost completely

*Corresponding author.

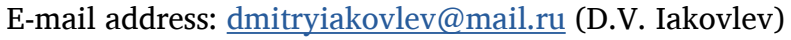




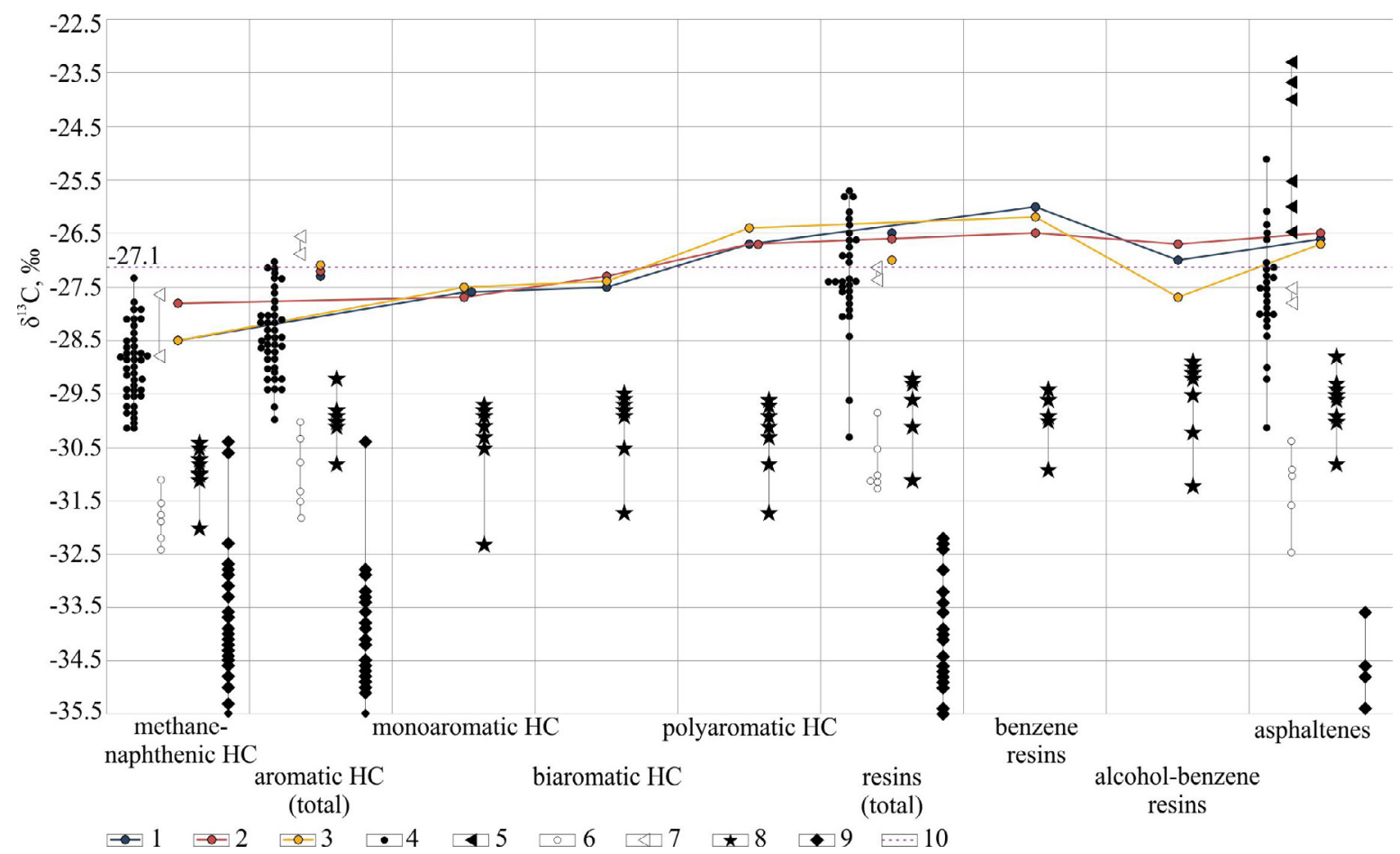

Fig.1. Carbon isotope-fractional curves in different types of Lake Baikal oils. 1-«Tolstoye» (from the ice); 2-«Gorevoye» (from the ice); 3-«Gorevoye»(the bottom); 4-The Perm Pre-Urals region (Paleozoic); 5-North Sakhalin (Miocene); 6-The western Pre-Caucasian region (Tertiary); 7-The western Pre-Caucasian region (Cretaceous); 8-Western Siberia oil and gas bearing province (Krasnoleninskaya, Sredneobskaya, Pur-Tazovkskaya oil and gas bearing regions); 9-Leno-Tungusskaya oil and gas bearing province (Baykitskaya, Katangskaya, Nepsko-Botuobinskaya, Angaro-Lenskaya oil and gas bearing regions); 10-Mean value of $\delta^{13} \mathrm{C}$ for the oils of Lake Baikal in general; *(5,6,7-data and design concept by Galimov E.M. (1973); 8-data of Pavelieva Yu.N. (2017); 9-data of Dakhnova M.V. et al. (2011))

disappear against the background of the formation of difficult to separate «naphthenic-aromatic humps» in oil chromatograms). Moreover, it is known (Galimov, 1981) that the biodegradation of oils is characterized by the isotopic weighting of $\delta^{13} \mathrm{C}_{\text {methane-naphthene }}$ and $\delta^{13} \mathrm{C}_{\text {methane- }}$ naphthene $>\delta^{13} \mathrm{C}_{\text {oil }}$. A research of the carbon isotopic ratio reveals the visible convergence of the isotopicfractional curves for both the three oils in general and the two «most biodegraded» oils «Gorevoe»(the bottom) -«Tolstoye»(from the ice). For the «least bio-modified» oil «Gorevoe»(from the ice), the highest value of $\delta^{13} \mathrm{C}_{\text {methane-naphthene }}$ probably appears the presence in it $\mathrm{n}$-alkanes and other hydrocarbons of low boiling and volatile fractions isotopically increases the weight of the total methane-naphthenic hydrocarbon component of the oil (isotopic weighting of low boiling fractions during the formation of isotopically facilitated volatile hydrocarbons; Galimov, 1981, p. 221). It is supposed that the studied oils are close in biodegradation degree and the differences in the component composition are associated with migration features (in the sedimentary rocks, in the water column, water-sediment interface).

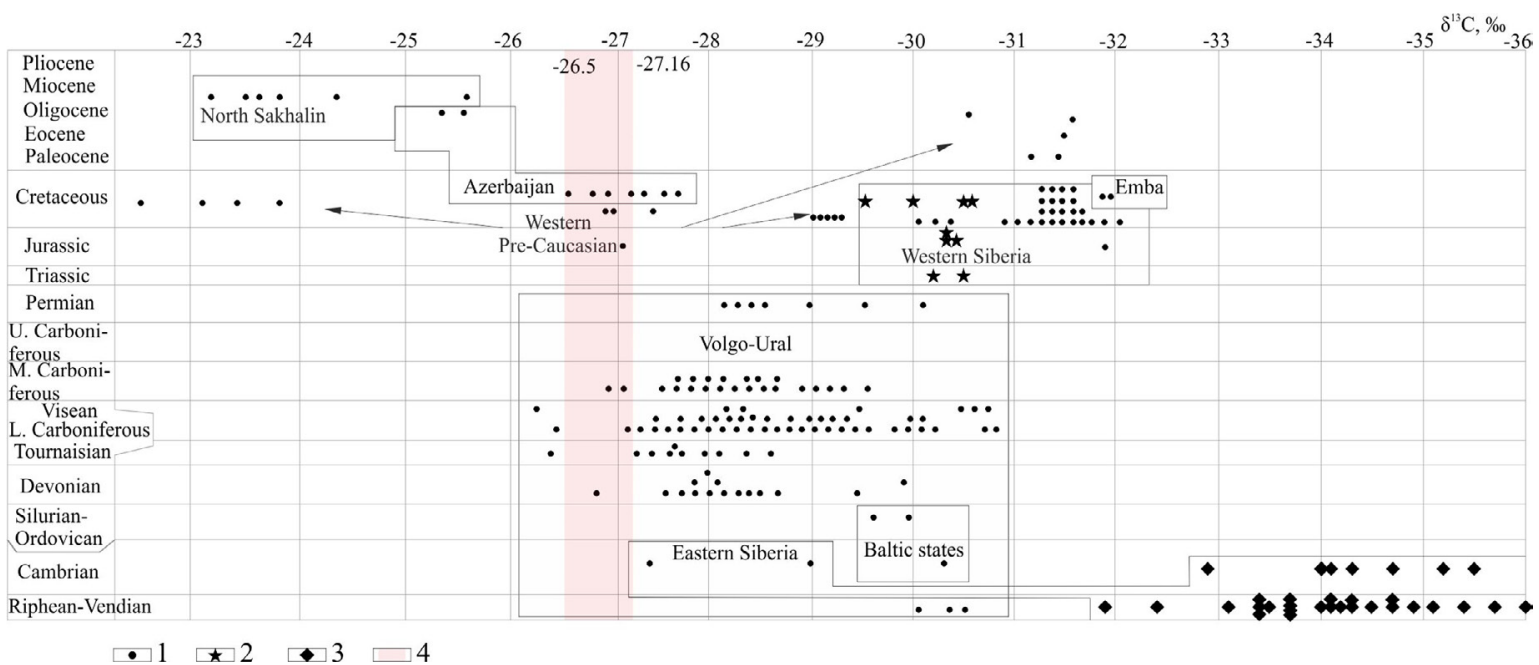

Fig.2. Carbon isotopic composition of oils of Lake Baikal in comparison with other areas. 1- data and design concept by Galimov E.M. (1973); 2-data of Pavelieva Yu.N. (2017); 3-data of Dakhnova M.V. et al. (2011); 4- interval of $\delta^{13} \mathrm{C}$ values measured in the oils of Lake Baikal and expanded by data of Kontorovich A.E. et al. $(1989 ; 2007)$ 


\section{Reference list}

Galimov E.M. 1973. Isotopy ugleroda v neftegazovoj geologii [Carbon isotopes in oil and gas geology]. Moscow: Nedra. (in Russian)

Galimov E.M. 1981. Priroda biologicheskogo frakcionirovaniya izotopov [Biological fractionation of isotopes]. Moscow: Nauka. (in Russian)

Dakhnova M.V., Kiselev S.M., Bazhenova T.K. et al. 2011. Isotopic criteria for predicting the phase composition of hydrocarbons in Riphean and Vendian deposits of the Lena-Tunguska petroleum province. Russian Geology and Geophysics 52: 945-953. DOI: 10.1016/j.rgg.2011.07.015

Kontorovich A.E., Drobot D.I., Presnova R.N. 1989. Geohimiya naftidov i problema genezisa bajkal'skoj nefti [Geochemistry of naphthides and problems of the Genesis of Baikal oil]. Sovetskaya geologiya [Soviet Geology] 2: 21-29. (in Russian)

Kontorovich A.E., Kashirtsev V.A., Moskvin V.I. et al. 2007. Petroleum potential of Baikal deposits. Russian Geology and Geophysics 48: 1046-1053. DOI: 10.1016/j. rgg.2007.11.004

Pavelieva Yu.N. 2017. Isotope-fraction analysis to diagnose genetic relationship of oils in Western Siberia. Final qualification work, Institute of Earth sciences (SPbSU), St. Petersburg, Russia. (in Russian) 